\title{
Environmental safety providing during heat insulation works and using thermal insulation materials
}

\author{
Evgeny Velichko ${ }^{1, *}$, Edward Tskhovrebov ${ }^{2}$, and Andrew Shevchenko ${ }^{3}$ \\ ${ }^{1}$ Moscow State University of Civil Engineering, Yaroslavskoe shosse, 26, Moscow, 129337, Russia \\ ${ }^{2}$ FBU NITSPURO, 121354, Moscow, Russia \\ ${ }^{3}$ National Engineering Company «GK NATEC», 121596, Moscow, Russia
}

\begin{abstract}
This article considers the negative effect of thermal insulating materials and products on human health and environment pollution, particularly in terms of the composition of environmentally hazardous construction products. The authors have analyzed the complex measures for providing ecological safety, sanitary and epidemiological requirements, rules and regulations both during thermal insulation works and throughout the following operation of buildings and premises. The article suggests the protective and preventive measures to reduce and eliminate the negative impact of the proceeding of thermal insulation works on the natural environment and on human health.
\end{abstract}

\section{Introduction}

Thermal insulating works provided for the protection of premises, structures, facilities and pipelines from undesirable heat transfer to the surroundings and for heat loss reduce, are the source of the negative impact on the environment and human health, worsening citizens' health and the environmental situation both during repairing works and throughout the following operation of buildings and premises. The same issues refer to heat-insulating materials and products used in construction works.

\section{Problem statement}

According to most literature sources, finishing works are considered to be the most dangerous in the term of impact on the environment and human health. The attention is focused on harmful emissions of volatile matters of paints and lacquers, mastics, glues and toxic compounds into the air from the surface of finishing materials made of PVC, plastics, plywood, chipboard and wood-fiber slabs, polystyrene foam during finishing works involving environmentally hazardous materials $[5,7,8]$.

However, it is worth noting that thermal-insulating works also make a significant contribution into the process of filling the environment with hazardous substances, which

\footnotetext{
* Corresponding author: pct44@yandex.ru
} 
are harmful for people and other life forms. Unlike finishing materials, which can be easily removed and replaced during a simple premise repair, toxic heat-insulating products installed inside the building envelope and ceilings can be removed and replaced only in the case of reconstruction or major repairs of the building. Neither ventilation nor treating with film-forming substances can help isolate toxic emissions emitted by heat-insulating materials owing to their location, which is structurally and technologically difficult to access. Therefore, choosing environmentally friendly harmless to human health thermal insulation materials during the design process and implementing them during planning and organizing the construction procedure is the key to the environmental safety of the construction operations as well as of the completed structure.

\section{Results and discussion}

During the execution of thermal insulation works the following materials of varying environmental hazard levels are used: plates, segments, insulating mats made of mineral, slag, glass, stone wool with synthetic binding; foam assembly, based on expandable polystyrene and polyurethane; blocks of rigid foam; asbestos and asbestos-containing materials; cellular thermal insulating concrete, cellular glass (foam glass), etc.

The authors analyzed the negative effect of these materials on the environment components. The analysis includes the assessment of the negative consequences. The results are shown in Table 1.

Table 1. Assessing the impact of environmentally hazardous thermal insulation materials on the environment.

\begin{tabular}{|c|c|c|}
\hline Material & Toxic substances released & Negative impact on the environment \\
\hline Asbestos & Asbestos dust & $\begin{array}{c}\text { Air pollution, vegetation, formation } \\
\text { of extremely hazardous waste }\end{array}$ \\
\hline Mineral wool & $\begin{array}{c}\text { Dust of mineral fibers and synthetic } \\
\text { binder }\end{array}$ & $\begin{array}{c}\text { Air pollution, hazardous waste } \\
\text { production }\end{array}$ \\
\hline Slag wool & Slag fiber dust & $-/ /-$ \\
\hline Fiberglass & $\begin{array}{c}\text { Dust of dry polyester resin and } \\
\text { fiberglass }\end{array}$ & $-/ /-$ \\
\hline $\begin{array}{c}\text { Products of } \\
\text { penopoli-styrene }\end{array}$ & $\begin{array}{c}\text { Styrene, formaldehyde, benzene, } \\
\text { toluene, ethylbenzene, cumene, } \\
\text { methanol, phenol, }\end{array}$ & $\begin{array}{c}\text { air pollution, formation of highly } \\
\text { hazardous waste }\end{array}$ \\
\hline $\begin{array}{c}\text { Polyurethane } \\
\text { foam mats on } \\
\text { the basis } \\
\text { penopoli- } \\
\text { urethane }\end{array}$ & $\begin{array}{c}\text { Mats on the basis penopoli-urethane, } \\
\text { isocyanates, butyl, butadiene, } \\
\text { ethylene glycol, ethyl acetate, } \\
\text { butanol, ethanol, isobutyl acetate, } \\
\text { benzene, acetone, } \\
\text { dimethylethanolamine }\end{array}$ & $\begin{array}{c}\text { Air pollution, formation of highly } \\
\text { hazardous waste }\end{array}$ \\
\hline
\end{tabular}

Within the process of technological improvements, which is the part of the construction and repair works, asbestos-containing materials possess environmentally and toxicologically dangerous properties. If compare with lump products containing asbestos and posing low harm to the environment, asbestos dust in the form of tiniest asbestos fibers is extremely toxic because of getting into the atmosphere during a cutting or drilling process, or during the wearing-off and abrasion period while the asbestos-containing product is operated. The workers involved in handling asbestos while construction works are carried out are at the increased risk of disease owing to the exposure to asbestos. The level of asbestos dust danger for people's health is influenced by various factors including a 
size, a method of fibers destruction under various types of asbestos handling, a dose and duration of fibres staying in the lungs.

Asbestos dust cause mechanical damage of the respiratory tract mucosa and lung tissue. Inhalation exposure to asbestos leads to the disease called asbestosis, which comes out with bronchi thickening and hardening, pulmonary fibrosis, characterized by a large flow rate and a low level of recovery. Asbestos dust content in the atmosphere is strictly rationed in sanitary and hygienic norms taking into account its' extreme danger, which belongs to the first class of hazard. Asbestos boards and partitions, used for finishing the interior, are required to have a two- or three-time covering, excluding the possibility of formation and distribution of asbestos-containing dust. All work with asbestos insulation is carried out in special suits with respiratory protection and protection of skin and eyes $[5,13,17,18]$.

Mineral wool, which is a generalized number for all inorganic fibrous materials, is produced of basalt rock (rock wool), the molten silica sand with the addition of glass waste (glass wool), and of the molten slag of metallurgical wastes (slag wool).

Products of the mineral wool with high thermal insulation properties affect negatively in various degrees on the environment and human health. Slabs of mineral wool with synthetic binder insulation materials synthetic binder (synthetic resins: urea resin and urea formaldehyde resin) provide the mineral wool with hazardous environmental characteristics under certain conditions.

Under high humidity conditions and elevated above-zero or reduced below-zero temperatures slag wool being a kind of mineral wool, which is produced of metallurgical slag melts with the following mixture processing into vitreous fibers with the addition of up to $4.5 \%$ organic additives as a binder component (synthetic resin, dust remover, hydrophobizing), loses its insulating properties and decomposes releasing toxic substances into the air $[10,12]$.

Mats, shells, slabs of glass wool based on fiberglass, produced by recycling of cullet with the adding molten quartz sand in staple glass fibers, which are held together with toxic polyester resins, are used for thermal insulation of frame structures of buildings and facilities, partition walls and pipelines with temperatures up to $450^{\circ}$. Toxic polyester resins can release vapors of the following hazardous compounds into the atmosphere: pthtalic aldehyde, ethylene glycol, diethylene glycol, ethylbenzene and styrene [9]. When the maximum permissible concentrations of ethylene glycol and diethylene glycol are exceeded, it impairs the skin and affects negatively the kidneys and central nervous system. Under the phthalic anhydride intoxication ocular and respiratory tract mucosa are irritated and disorders of the nervous system and bone marrow hematopoiesis are noticed. Dry polyester resin dust and fiberglass dust pose a risk to human health if their influence exceeds the maximum safe exposure level defined for these substances by sanitary standards.

Construction works involving the use of glass wool, mineral wool or slag wool may contribute to occurring such chronic dust lung diseases as silicosis and pneumoconiosis. The risk of disease is determined by sequel severity of chronic bronchitis, emphysema or pneumonia. Contacting with the skin glass fiber causes irritation and subsequent dermatitis developing. In order to prevent diseases mentioned above while working with mineral wool it is vitally important to follow the safety rules, including the obligatory use of personal protection equipment for mucous membranes, skin and respiratory system protecting $[1,3]$.

Extruded expended polystyrene and other materials of varying environment hazard levels made of polystyrene and polyurethane are widely used as thermal insulation materials in the form of slabs, mats, sections used for the wall, roof and sound insulation. The most important factor determining the thermal insulation properties of expanded polystyrene, which consists of only $2 \%$ of polystyrene, is the air closed in cells having a very high thermal insulation performance. The expanded polystyrene, produced of 
suspended polystyrene and the expanding agent - porogene, is used as the middle layer of thermal insulation of building structures. The foamed polystyrene has properties, which are hazardous to human health, because of toxic compounds emitting the polymerization into the atmosphere under the condition of incomplete polymerization and combustion. These compounds are styrene, alpha-methyl styrene, benzene, toluene, ethylbenzene, cumene, methanol, formaldehyde $[8,9]$.

Styrene and its derivatives (polystyrene and expanded polystyrene) have high toxicity and are capable to emit harmful substances from the surface into the atmosphere continuously for a long period. According to the sanitary code requirements, styrene should not contact either premises or ventilated air. The excess of the one-time or daily average maximum allowable concentration of this toxic compound in the air should be unacceptable. A toxic effect of styrene on human health is the reason of such stringent requirements. Its vapors are highly irritating for the eyes and mucous membranes, cause headaches, nausea, dizziness, spasms and blackouts. The clinical finding of intoxication with styrene possessing narcotic action includes negative changes in the central nervous system and liver toxicity. Benzene and ethylbenzene (toxic hydrocarbons migrating from the foam surface into the premises) contribute to the development of various dangerous diseases. Exceeding the maximum allowable concentration of ethylbenzene in the inhaled air can cause the inflammation of the mucous membranes and dizziness, vascular and central nervous system damage. Intoxication with highly hazardous benzene compound is always accompanied by central nervous system damage and brain damage, which are also appearing during intoxication with poisons, possessing narcotic effect $[1,3]$.

The negative impact on human can be caused by the decomposition products of blowing agents (such as dinitrile azoizomaslyanoy acid), evolved into the air. Blowing agents (nitrogen, carbon dioxide, ammonia and others) are added into foam plastics to form a porous structure of the material. These low hazard (if the concentration in the air is permissible) gases are able to react actively with the substances contained in the indoor air (oxygen, hydrogen sulfide, aerosols, heavy metals, etc.) forming compounds which are more dangerous for human health .

Insulating panels of foam based on resole phenol-formaldehyde resins are the most toxic in the term of effects on human health, since formaldehyde and phenol, the highly dangerous compounds, can enter the air within the operation process companying the harmful substances mentioned above.

Compared with insulating panels based on polystyrene hard mats and polyurethane foam are much more toxic to the environment and human health, being manufactured on the basis of such environmentally hazardous components as polyisocyanates and polyols. The polyol component consists of a mixture of simple and complex polyesters, amine catalysts, stabilizers, flame retardant, water or freon as a chemical blowing agent. The polyisocyanate is a liquid used in casting and spray-on systems for manufacturing rigid thermally insulating polyurethane foam. Materials of polyurethane foam are capable to release isocyanates into the air, which are carcinogens (e.g., toluene diisocyanate), and a number of other hazardous compounds, such as butadiene, ethylene, benzene, ethyl acetate, butyl acetate, isobutyl acetate, acetone, ethanol, butanol and dimetiletalonamin. Installation foam also contain a mixture of vapor and aerosol of 4,4-diphenyl-metandiizotsianata (MDI), which is dangerous if inhaled and can cause allergic reactions and eye, respiratory tract and skin irritation $[8,14]$.

In the term of hygienic safety, men should strictly follow the rules of safety and labor protection during the construction works if thermal insulation products used in works contain polystyrene or polyurethane foam after all. Taking into account that the polystyrene dust enters the air at the time of cutting foam slabs and that toxic impurities are emitted while spraying polyurethane into the air, one should take measures to use of personal 
protective equipment for eyes, respiratory ways and skin and to execute complete cleaning the room from the dust. The primary measure is to prevent the formation of excessive styrene vapor concentration in the indoor air. For this purposes free access of clean air into the premises is provided through aeration or ventilation system. Preventing contact with polystyrene and polyurethane materials is achieved by the vapor barrier in the wall, which is realized by the outer foil, wallpaper or drywall boards covering, (providing the membranes for letting the vapor out in special points). Compliance with safety regulations helps to reduce the impact of these toxic compounds on a human body even if the contact with them is unavoidable owing to several reasons [11].

In order to protect the environment and human health it is reasonable to minimize the use of thermal insulation products manufactured on the basis of expanded polystyrene. Whereas the use of other products, which are less toxic but have all the same useful structural and positive physical and chemical properties, is also should be increased [4]. For example, cellular glass (foam glass) could be such an alternative, because it is environmentally friendly material used for insulation and walling.

Silicone, acrylic and silicate sealant, which are low hazardous for human health, are widely used for heat and water proofing the external and internal structures. The exception is foam, which is also widely used, but dangerous.

In order to improve environmental performance of cellular concrete used for thermal insulation in the manufacturing process they use fast hardening Portland cement and such natural inorganic and organic fillers as wood chips, sawdust, crushed stone and other nontoxic materials.

As a more environmentally secure alternative, it is reasonable to use thermal insulation materials based on mineral (basalt), waste of lint manufacturing, wood and other natural materials without the use of toxic resins as binders, instead of using glasswool or rockwool slabs and slabs of expanded polystyrene.

Today environmentally friendly insulation materials are insulating panels of wood origin with high insulation properties and environmental and health indicators. Their insulating ability is much higher than insulating ability of slab types of insulating materials, due to the absence of slots, joints, seams and the product bearing against the basis. Due to boron sanitizers in the composition, this material protects the insulated surface from decay, fungi, rodents, and insects. It belongs to hard inflammable products maintaining its insulating ability during the fire and significantly slowing down the spread of fire. Ecowool consisting for more than $80 \%$ of wood fibers infiltered with boric acid does not contain toxic substances, which would be harmful to the environment and human health under normal operating conditions and under heating.

Reflective insulation of foil is very environmentally friendly. Instead of emphasizing the thickness and density of conventional insulating materials, foil blocks heat and cools the room using its reflectance. Works with adhesive foil, unlike the traditional tile insulation, do not require protective clothing during installation and do not represent any danger to lungs, skin and eyes.

One of the most promising ways to solve the resource problems and improve the environmental safety in construction, comfort and hygiene of housing is the development of nanotechnology in the production of modern building materials. In the EU, the US, Japan and China, nanotechnology have already been successfully contributing to the effective development of the construction industry, preserving natural resources, improving the environment and life safety and quality. Systematic researches and developments in the field of thermal insulation and nanomaterial are being held. The main attention is focused not only on the home environment, but also on conserving energy resources $[15,16]$. Researchers from the British University of Nottingham located in Ningbo (China), created a new thermostatic building material, capable of absorbing excess heat and release it back if 
it is necessary. It will significantly reduce the costs of heating, air conditioning and maintenance of indoor climate. Innovative development belongs to the class of phase change materials (PCM), which means absorbing or, on the contrary, giving off heat by changing its aggregation state at a certain temperature. In order to ensure insulation and retain heat in the rooms, scientists of the Technological Institute of Massachusetts have designed the new material of nanoscale carbon tubes with azobenzene, which attracts solar radiation, being not only the storage of heat, but also solar radiation converter therein. In addition, it does not lose its properties over time and is able to store heat.

Since the 90s, the novation technologies of various building products manufacturing are being actively implemented in Russia. The main development vector of these technologies is resource conservation, sanitary-hygienic and environmental safety, reliability, efficiency and optimal use in the construction industry. In our country, the most promising types of environmentally friendly thermal insulation materials using nanotechnology are the following:

- Liquid insulation presenting one coating layer $0,4 \mathrm{~mm}$ thick in the form of a suspension of silica nanoparticles with acrylic binder, which is widely used due to its low thermal conductivity: not more than $0.02 \mathrm{~W} /(\mathrm{m} * \mathrm{~K})$; wide operating temperature range from -60 up to $+220^{\circ} \mathrm{C}$. It possesses reflectivity for thermal radiation, anti-corrosive, nonflammable properties for heat insulation of hot and cold water pipelines, construction of residential and industrial buildings;

- Similar insulating coating in the form of nano-paints, structured silicone and evacuated ceramic microspheres of which create a power frame cover during painting. The frame has a high thermal resistance due to the longitudinal-layered structure in the form of films separated by thinnest air gaps, contributing to the formation of elastic, impervious dropping moisture multilayer, heat-reflecting coating, blocking all the heat flow $[2,6]$.

The authors of the article have defined the criteria of ecological safety of thermal insulating construction products, presenting materials and products, which possess the following properties under all operating conditions including changes of temperature, humidity, vibration and solar radiation:

- have a level of radioactivity below background values;

- do not contain volatile and extremely highly toxic compounds;

- do not release solid or gaseous substances belonging to 1,2 or 3 class of danger into the air during the destruction, aging or wear process

- do not react with substances in the water, air or soil, forming class 3.1 toxic compounds;

- do not have a biologically dangerous effect on people or the environment;

- are explosion-proof and do not form products, which are fatal to human health, in a fire or thermal decomposition;

- do not violate safe indoor climate, particularly temperature, floor thermal conductivity, electromagnetic and geomagnetic background, dust level, insolation, relative humidity, ionic composition, smell, colors) [12,13].

The authors are convinced that there is a necessity to implement a number of normative resulting indicators of construction works and materials, which will enable to assess the environmental safety, resource use and level of secondary raw materials, energy and waste utilization. These indicators would include:

- Ecological capacity (ECO) - the environmental costs (environmental payments as an allowance for ecological and economic damage to the environment, the fee for natural resources and for environment protecting measures) per unit of output produced or repair and construction works:

$$
E C O=E c / C p
$$

$E c$ - the value of environmental costs in terms of value; 
$C p$ - the annual realization of construction products in terms of value or cost of implementing construction works.

- The secondary resource productivity (Srp) - the output of construction products from the unit of used secondary energy, raw materials, waste. Weight or cost of construction products to the weight or cost of secondary materials and waste used in those products ratio:

$$
S r p=C p / S s . r .
$$

Ss.r. - the cost of secondary material, energy or waste resources used for the manufacture of construction products.

- Product resource-saving $(\mathrm{Pr})$ - the cost of secondary material resources in the cost of realized construction products:

$$
\operatorname{Pr}=\text { Ss.r. } / C p
$$

For a comprehensive ecological and hygienic assessment it is necessary to examine and evaluate the entire range of negative qualities of thermal insulation products. Products should be studied in terms of influence on the environment and human health, of the material safety at all the following stages of the cycle: production, use in the construction, repair and operation process, taking into account that the choice of interior material influences not only the comfort, but also the security of human life.

\section{Conclusions}

The authors basing on available information have held the complex classification and comparison study of the negative impact of thermal insulation works and materials on the environment and human health assessing their environmental risk.

According to the results of the analysis, the environmental safety of the insulation work process can be achieved through the sanitation and environmental requirements providing when handling building materials both at the stage of construction and at the design stage. The main directions of ecologization process include the following measures: implementing the best of advanced environmentally friendly building technologies and low-waste or nonwaste technological processes; selecting environmentally friendly materials; strict regulating the use of thermal insulation materials, even with low-risk properties; prohibiting the use of products emitting extremely and high toxic compounds; executing hygienic evaluation and certification not only of construction products, but also of the raw material for their manufacturing. Increase of energy efficiency in actual structure erecting, repairing and maintaining processes have become an important tool to ensure the environmental safety of residential property. The points of energy efficiency are improving the insulation of existing residential and non-residential premises by using innovative heat-saving structures, durable and safe thermal insulation materials, control and heat savings.

\section{References}

1. T. Y. Bindyuk, O. V. Besschetnova, Professional'nyye bolezni, (SGU, 128, 2007)

2. V. A. Voytovich, Rukovoditel' stroitel'noy organizatsii, 2, 4-19 (2011)

3. S. R. Gil'denskiol'd, Vozdeystviye na organizm cheloveka vrednykh $i$ opasnykh fizicheskikh proizvodstvennykh faktorov. Mediko-biologicheskiye aspekty (Izdatel'stvo Standartov, Moscow, 2004)

4. S. R. Gil'denskiol'd, L. P. Aksenova, G. M. Kuznetsova, Polimernyye $i$ polimersoderzhashchiye materialy $i$ konstruktsii, razreshennyye $k$ primeneniyu $v$ stroitel'stve (Minzdrav Rossii, Moscow, 2002) 
5. A. P. Il'nitskiy, Kantserogennyye faktory zhilishcha (Mezhdunarodnaya akademiya, Moscow, 1995)

6. P. G. Kudryavtsev, O.L. Figovskiy, Nanotekhnologii v stroitel'stve, 6, 27-45 (2014)

7. V. K. Litskevich, Zhilishchnoye stroitel'stvo, 4, 24-26 (2011)

8. L. A. Maksanova, O. Z. Ayurova, Polimernyye soyedineniya $i$ ikh primeneniye (VSGTU, Ulan-Ude, 2004)

9. Russian Standard MU 2.1.2.1829-04 .

10. V. U. Novikov, Polimernyye materialy dlya stroitel'stva: Spravochnik (Vysshaya shkola, Moscow, 1995)

11. Russian Standard SanPiN 2.1.2.729-99.

12. E. S. Tskhovrebov, Obespecheniye ekologicheskoy bezopasnosti pri proyektirovanii ob"yektov nedvizhimosti i provedenii stroitel'nykh rabot (RGGMU, St.-Petersburg, 2013)

13. E. S. Tskhovrebov, Y. G. Velichko, Stroitel'nyye materialy, 5, 99-103 (2014)

14. A. A. Askadslcii, Physical Properties of Polymers, Prediction and Control. Gordon and Breach (New York, 1996)

15. International Symposium on Recycling of polymers: Science and Technology: Marbella, Spain, 18-20 September, 57, 395 (1992)

16. G. E. Zaikov, M. I. Artsis, A.Y. Polishchuk, Polym. News, 9, 323-324 (1996)

17. L. Welch, D. Michaels, S. Zoloth, Am. J. Ind. Med, 18 (1994) 